\title{
Oscillation of differential equations with non-monotone retarded arguments
}

\author{
Özkan Öcalan
}

This paper, which was published on 3 November 2015, has been withdrawn. 
